\title{
PROSOCIAL BEHAVIOR DAN PERSEPSI AKUNTABILITAS PENGELOLAAN DANA DESA DALAM KONTEKS BUDAYA TRI HITA KARANA
}

\author{
Ni Luh Ayu Mahayani' \\ ${ }^{1}$ Fakultas Ekonomi dan Bisnis Universitas Udayana, Bali, Indonesia \\ email: ayumaha82@gmail.com
}

\begin{abstract}
ABSTRAK
Penelitian bertujuan menguji pengaruh kompetensi, partisipasi, dan kepemimpinan dengan prosocial behavior sebagai variabel moderasi terhadap akuntabilitas pengelolaan dana desa dalam konteks budaya Tri Hita Karana. Akuntabilitas pengelolaan dana desa dalam konteks budaya Tri Hita Karana mengandung makna pertanggungjawaban secara menyeluruh hubungan harmonis manusia dengan Tuhan, hubungan harmonis sesama manusia dan hubungan harmonis dengan alam. Sampel penelitian menggunakan 48 aparat pemerintah desa di Kabupaten Karangasem, Provinsi Bali. Data penelitian dikumpulkan dengan survey menggunakan kuesioner. Data diambil secara cluster random sampling. Analisis data menggunakan partial least squares (PLS). Hasil penelitian menunjukkan kompetensi sumber daya manusia dan partisipasi masyarakat berpengaruh positif pada akuntabilitas pengelolaan dana desa. Kepemimpinan tidak ditemukan bukti empiris berpengaruh pada akuntabilitas pengelolaan dana desa. Prosocial behavior memperlemah pengaruh kompetensi sumber daya manusia pada akuntabilitas pengelolaan dana desa. Prosocial behavior memperkuat pengaruh partisipasi masyarakat pada akuntabilitas pengelolaan dana desa. Prosocial behavior tidak ditemukan bukti empiris memperkuat pengaruh kepemimpinan pada akuntabilitas pengelolaan dana desa.
\end{abstract}

Kata kunci: Akuntabilitas dana desa, akuntabilitas berbasis budaya tri hita karana, prosocial behavior

\section{PROSOCIAL BEHAVIOR AND ACCOUNTABILITY PERCEPTION OF VILLAGE FUND IN THE CONTEXT OF TRI HITA KARANA CULTURE}

\begin{abstract}
This study aims to examine the influence of competence, participation, and leadership with prosocial behavior as a moderating variable in accountability of village fund management. The analysis unit of this study are the village officials in Karangasem Regency in the year 2016. Data were collected through questionnaires and the samples are chosen by cluster random sampling. Data analysis technique used in this study is the analysis of partial least squares (PLS). The test results showed that the competence a positive effect on the village fund management accountability. Participation of the community gave a positive effect on the village fund management accountability. Prosocial behavior weakens the influence of the human resources competence on the village fund management accountability. Prosocial behavior strengthen the influence of community participation in village fund management accountability. Prosocial behavior weakens the influence of leadership on the village funds management accountability.
\end{abstract}

Keywords : Village funds accountability, tri hita karana culture, prosocial behavior DOI: https://doi.org/10.24843/JIAB.2017.v12.i01.p07

\section{PENDAHULUAN}

Prioritas ketiga Nawacita dinyatakan pemerintah akan membangun Indonesia dari pinggiran dengan memperkuat daerah-daerah dan desa dalam kerangka Negara Kesatuan Republik Indonesia. Kebijakan Nawacita pemerintah berimplikasi pada disetujuinya anggaran dana desa sejumlah Rp 20,7 triliun yang tertuang dalam Anggaran Pendapatan dan Belanja Negara Perubahan (APBNP) tahun 2015. Pada tahun 2016 dana desa meningkat menjadi Rp 46,9 triliun yang disalurkan kepada 74.754 desa di seluruh Indonesia.

Pada tahun 2015, pemerintah Kabupaten Karangasem, Provinsi Bali mengalokasikan dana desa sebesar Rp 21.962.811.000,00 dan pada tahun 2016 sebesar Rp 49.301.984.000,00 yang telah disalurkan kepada 75 desa yang tersebar di delapan kecamatan. Prioritas penggunaan dana desa digunakan untuk membiayai penyelenggaraan pemerintahan, 
pembangunan, pemberdayaan masyarakat, dan kemasyarakatan (Perbup. No. 23 Tahun 2015).

Jumlah pendapatan yang diterima desa menimbulkan kekhawatiran mengenai kesiapan desa dalam mengelola dana tersebut. Isu yang muncul adalah pentingnya akuntabilitas dalam mengelola dana desa. Akuntabilitas dimaksudkan untuk memastikan kepercayaan masyarakat terhadap pemerintah serta menjembatani kesenjangan antara masyarakat dengan pemerintah (Aucoin dan Heintzmen, 2000). Dalam membangun kepercayaan tersebut, organisasi sektor publik harus membangun akuntabilitasnya atas dasar harapan para prinsipal, bukan demi kepentingan agen semata (Randa dan Daromes, 2014). Akuntabilitas juga dimaksudkan sebagai mekanisme pertanggungjawaban atas kinerja pejabat publik yang dijabarkan melalui tindakan yang sesuai dengan peraturan dan perilaku etis (Scott 2000; Mulgan 2003).

Akuntabilitas bukan sekadar pertanggungjawaban keuangan secara formal suatu organisasi, tetapi merupakan pertanggungjawaban yang meliputi kepatuhan pada peraturan, lingkungan organisasi, masyarakat, dan pemerintah (Patton, 1992). Akuntansi sebagai alat pertanggungjawaban tidak hanya memerhatikan pengelolaan dana, namun juga memerhatikan dampak sosial dan alam lingkungannya. Akuntansi dibentuk oleh kultur masyarakat, sistem ekonomi, politik, dan sosial lingkungan akuntansi (Triyuwono, 2000).

Akuntabilitas dalam konteks Tri Hita Karana adalah tuntutan akuntabilitas dalam konteks hidup bermasyarakat guna mencapai keserasian hubungan manusia dengan Tuhan, sesama, dan alam lingkungannya (Randa, 2013). Hal ini sesuai dengan pemahaman akuntabilitas dalam konteks budaya Tri Hita Karana yang dinyatakan ( Sujana et. al., 2015; Ariyanto, 2014) bahwa individu sebagai agen mempunyai tiga prinsipal yakni kepada Tuhan sebagai pencipta, manusia sebagai makhluk sosial, dan alam lingkungan tempat manusia itu hidup.

Dalam kajiannya yang dilakukan sejak Januari 2015, Komisi Pemberantasan Korupsi (KPK) mencatat 14 potensi penyelewengan dana desa yang meliputi aspek regulasi dan kelembagaan, tata laksana, pengawasan, dan sumber daya manusia (www.kpk.go.id). Laporan Hasil Pemeriksaan (LHP) Badan Pemeriksa Keuangan Republik Indonesia atas belanja dana desa tahun anggaran 2015 dan 2016 di Kabupaten Karangasem menjabarkan bahwa pengelolaan keuangan desa dan perencanaan pengadaan barang dan jasa belum sesuai ketentuan. Pemanfaatan dana desa belum sesuai dengan prioritas penggunaan dana desa. Terdapat penggunaan dana desa yang tidak tepat sasaran. Pelaksanaan kegiatan fisik yang bersumber dari dana desa tidak tertib, menyebabkan adanya kelebihan pembayaran atas pekerjaan fisik dan mengakibatkan kerugian negara.

Damayanti (2009) menyatakan ideologi dasar organisasi sektor publik (khususnya pemerintahan) adalah memaksimalkan social welfare dengan mengutamakan kepentingan publik dan pelayanan kepada masyarakat. Program dana desa dimaksudkan untuk meningkatkan kesejahteraan masyarakat desa dengan pembangunan yang bersifat partisipatif dan memberdayakan masyarakat.

Agency theory akan relevan digunakan untuk menjelaskan hubungan prinsipal dan agen dalam pengelolaan dana desa. Eisenhardt (1989) menyatakan agency theory dapat digunakan dalam memahami hubungan principal dan agent ketika program yang dilakukan atau aktivitas yang dilakukan agent sulit untuk diukur keberhasilannya. Mardiasmo (2006) menyatakan salah satu ukuran dari adanya akuntabilitas adalah laporan keuangan. Bentuk akuntabilitas pengelolaan dana desa kepada para stakeholder-nya di antaranya dalam bentuk formal laporan keuangan. Setiap departemen dan lembaga pemerintah harus membuat laporan keuangan dan laporan kinerja (Akinbuli, 2012). Laporan pertanggungjawaban pemerintah yang efisien, efektif, dan ekonomis (value for money) merupakan bentuk dari akuntabilitas suatu daerah (Binawati, 2014).

Kemampuan administratif adalah "core of government" dan komponen penting dalam melaksanakan pemerintahan (Farazman, 2009). Pemerintahan yang kemampuan administratifnya lemah, biasanya mengalami masalah dalam pengelolaan keuangannya (Hughes et. al., 2004). Nurjaman (2015) dan Karauwan (2013) menyatakan keberhasilan pembangunan desa dipengaruhi sejumlah faktor, seperti kapasitas perangkat desa, partisipasi masyarakatnya, serta kepemimpinan dari kepala desa. Terdapat keterkaitan antara faktor sumber daya manusia dengan penguatan program alokasi dana desa (Tuan, 2009). Dalam mengelola dana desa diperlukan aparat pemerintah yang memiliki kemampuan serta bertanggung jawab mengelola dana tersebut (Fajri et. al., 2014). Faktor yang menjadi penghambat pengelolaan keuangan desa adalah terbatasnya kemampuan aparatur pemerintahan desa dan lemahnya kinerja pengelolaan keuangan desa (Diansari, 2014). 
Penelitian-penelitian tentang akuntabilitas keuangan dan kinerja instansi pemerintah telah banyak dilakukan, antara lain Santoso (2016) menjelaskan bahwa kompetensi sumber daya manusia berpengaruh signifikan pada akuntabilitas keuangan daerah. Penelitian Rofika dan Ardianto (2014) mendapatkan hasil bahwa kompetensi SDM tidak berpengaruh pada akuntabilitas kinerja instansi pemerintah. Penelitian Arifin (2007) membuktikan partisipasi masyarakat dan kepemimpinan kepala desa mempunyai pengaruh terhadap keberhasilan pembangunan desa. Sejalan dengan penelitian Listya (2011), penelitian Kurniawan (2011) menunjukkan hasil bahwa partisipasi masyarakat mempunyai pengaruh yang positif pada akuntabilitas penyusunan Anggaran Pendapan dan Belanja Daerah (APBD). Hasil yang berbeda didapatkan dalam penelitian Raharja et. al., (2015), Lestari (2014), dan Retnaningtyas (2016) yang menunjukkan bahwa partisipasi tidak berpengaruh pada akuntabilitas kinerja keuangan SKPD. Penelitian Supartha (2006) menyatakan bahwa tidak ada pengaruh kepemimpinan terhadap akuntabilitas kinerja keuangan organisasi. Berbeda dengan yang dikemukanan Barlan (2010) bahwa pengelolaan program pembangunan dapat berjalan dengan baik jika tokoh pemerintah dapat mengetahui kepentingan publik dan dapat bekerja sama dengan masyarakat.

Perbedaan hasil penelitian menjadikan argumentasi research gap yang mendorong peneliti untuk memasukkan variabel moderasi. Pendekatan kontingensi diperlukan untuk dapat mengidentifikasi variabel lain yang bertindak sebagai pemoderasi ataupun pemediasi dalam model riset (Murray, 1990). Telaah penelitian membuktikan bahwa faktor kondisional mampu memoderasi hubungan antara variabel bebas dan variabel terikat. Ada empat klasifikasi faktor kondisional tersebut yaitu: kultur, organisasional, interpersonal, dan individual (Brownell, 1982). Penelitian ini mendefinisikan ulang akuntanbilitas dalam konteks budaya Tri Hita Karana yang ada di Bali.

Bagi masyarakat desa adat Bali, terdapat jiwa dan semangat dalam diri setiap perangkat desa dan kepercayaan yang diberikan oleh masyarakatnya dalam bentuk pengabdian (ngayah) Wirajaya, (2014). Dengan demikian, setiap individu dalam masyarakat merasa mempunyai kewajiban dan ikhlas melaksanakan tugas tanpa memikirkan imbalan yang akan diterima (Damayanti, 2009). Perbuatan yang suka menolong atau kesukarelaan dan pengabdian diri yang tulus tanpa memikirkan imbalan tidak lepas dari perilaku prososial (Widyarini, 2005).
Teori peran (role theory) memberi penelaah terhadap perilaku sosial dalam masyarakat. Perilaku sosial seseorang dalam sebuah kelompok merupakan hasil aktualisasi dari suatu peran tertentu (Myer, 2002). Peran aparat pemerintah desa menduduki posisi sosial dalam masyarakat dan dipercaya oleh masyarakat dalam mengelola keuangan desa. Teori kualitas Crosby (1989) menyatakan agar sesuai dengan yang distandarkan, suatu produk atau jasa harus dikerjakan oleh orang yang memiliki skills tinggi (kompeten) dan attitudes atau behavior yang baik. Teori peran dan teori kualitas digunakan untuk memasukkan prosocial behavior sebagai faktor kontingensi. Faktor prosocial behavior berperan sebagai pemoderasi hubungan antara kompetensi sumber daya manusia, partisipasi masyarakat, dan kepemimpinan pada akuntabilitas pengelolaan dana desa.

Akuntablitas pengelolaan dana desa difokuskan dalam konteks budaya Tri Hita Karana yang merupakan landasan filosofis dan religius dari lahirnya desa adat di Bali (Surpha, 2004:8). Budaya Tri Hita Karana merupakan kearifan lokal Bali yang digunakan sebagai landasan dalam aktivitas kehidupan bermasyarakat (Suardhika, 2013, Ariyanto, 2014). Akuntabilitas ditujukan kepada Tuhan, para stakeholder dan alam lingkungannya. Hal ini sesuai dengan visi Kabupaten Karangasem yaitu pemerintahan yang cerdas, bersih, dan bermartabat berlandaskan Tri Hita Karana.

Dari uraian tersebut, maka penelitian ini mengkaji masalah apakah kompetensi sumber daya manusia, partisipasi masyarakat dan kepemimpinan berpengaruh pada akuntabilitas pengelolaan dana desa. Apakah perilaku prososial memperkuat hubungan (memoderasi) kompetensi, partisipasi dan kepemimpinan pada akuntabilitas pengelolaan dana desa.

Hasil penelitian dapat memperkuat atau menambah bukti empiris mengenai teori keagenan, teori kepatuhan, teori situasional model kepemimpinan kontigensi, teori peran dan teori kualitas. Penelitian juga dapat digunakan sebagai bahan pertimbangan oleh pemerintah Kabupaten Karangasem dalam menetapkan suatu regulasi atau kebijakan dalam upaya meningkatkan akuntabilitas pengelolaan dana desa.

Teori keagenan akan relevan digunakan untuk menjelaskan hubungan prinsipal dan agen dalam pengelolaan dana desa. Eisenhardt (1989) menyatakan agency theory dapat digunakan untuk memahami hubungan principal dan agent ketika program yang dilakukan atau aktivitas yang dilakukan agent sulit untuk diukur keberhasilannya. 
Pemahaman akuntabilitas dalam konteks budaya Tri Hita Karana menyatakan bahwa individu sebagai agen mempunyai tiga prinsipal yakni Tuhan, manusia, dan alam lingkungan. Undang-undang No 6 Tahun 2014 mengamanatkan pengelolaan dana desa dengan melibatkan partisipasi masyarakat. Aparat desa harus bisa mempertanggungjawabkan pengelolaan dana desa secara menyeluruh. Kompetensi aparat pemerintah desa dan kepemimpinan kepala desa akan menentukan keberhasilan penyelenggaraan pembangunan desa.

Teori kepatuhan menyebutkan dua perspektif kepatuhan yaitu perspektif instrumental dan perspektif normatif. Perspektif normatif menimbulkan persepsi bahwa seseorang cenderung untuk mematuhi hukum yang sesuai dengan normanorma internal mereka dan berlawanan dengan kepentingan pribadi (Tyler, 1990). Kepatuhan seseorang akan aturan dan norma yang berlaku mencerminkan kompetensi seseorang. Keahlian atau kompetensi agen akan menentukan output. Pemahaman aparat pemerintah desa pada peraturan perundang-undangan yang berlaku mencerminkan kompetensi yang dimiliki oleh individu dalam organisasi pemerintah desa.

Kompetensi individu seperti keterampilan manajemen dalam semua organisasi merupakan faktor yang mutlak harus dimiliki aparatur. Kompetensi individu dibentuk juga oleh keahlian, yaitu hal-hal yang bersifat intelektual dan fisik (Saputra, 2010). Rendahnya kompetensi sumber daya manusia aparat desa menjadi hambatan dalam proses pengelolaan alokasi dana desa (Thomas, 2013). Penelitian Raharjo dkk. (2013) menunjukkan bahwa faktor kemampuan sumber daya manusia memengaruhi kinerja dari aparat pemerintah desa. Alimbudiono dan Fidelis (2004), Sudiarianti (2013) menunjukkan bahwa kompetensi SDM berpengaruh terhadap kualitas laporan keuangan dan kualitas laporan keuangan mempunyai pengaruh terhadap akuntabilitas keuangan (Fitriyah, 2013). Penelitian Santoso (2016) mendapatkan hasil bahwa kompetensi sumber daya manusia berpengaruh positif pada akuntabilitas keuangan daerah. Berdasarkan kajian teori kepatuhan dan riset-riset yang ada maka hipotesis pertama adalah:

$\mathrm{H}_{1}$ : Kompetensi sumber daya manusia berpengaruh positif pada akuntabilitas pengelolaan dana desa.

Teori keagenan pada sektor publik menjelaskan masyarakat sebagai prinsipal dalam hubungan keagenan mempunyai hak untuk mendapatkan pertanggungjawaban dari pengelolaan dana publik yang dilakukan oleh agen. Dalam pengelolaan keuangan desa, partisipasi masyarakat dapat meningkatkan pembangunan desa. Pembangunan masyarakat desa adalah gerakan pembangunan yang didasarkan pada peran serta masyarakat. Atas dasar itu maka kesadaran dan peran serta masyarakat perlu ditingkatkan, sehingga partisipasi masyarakat dalam pembangunan dirasakan sebagai suatu kewajiban bersama (Umboh, 2004). Perencanaan pembangunan desa yang ideal dilakukan oleh masyarakat desa secara partisipatif karena masyarakat desalah yang jauh lebih mengetahui dan mengerti masalah yang sesungguhnya ada di desanya dan potensi yang bisa digali untuk dikembangkan demi kemajuan desa (Umboh, 2004). Masyarakat desa diharapkan dapat berpartisipasi dalam perencanaan ABPDes, mengetahui secara transparan kondisi keuangan desa, dan pemerintah desa wajib bertanggungjawab mengelola keuangan (Hanifah dan Praptoyo, 2015)

Penelitian yang dilakukan oleh Listya (2011) dan Wulandari (2013) menunjukkan bahwa partisipasi masyarakat berpengaruh positif terhadap tingkat keberhasilan proyek program nasional pemberdayaan masyarakat mandiri perdesaan. Arifin (2007) mendapatkan hasil partisipasi masyarakat mempunyai pengaruh terhadap keberhasilan pembangunan desa. Kurniawan (2011), dan Sopanah (2003) menunjukkan bahwa partisipasi masyarakat mempunyai pengaruh yang positif terhadap akuntabilitas penyusunan APBD.

$\mathrm{H}_{2}$ : Partisipasi masyarakat berpengaruh positif pada akuntabilitas pengelolaan dana desa

Teori situasional model kepemimpinan kontingensi menyatakan bahwa keefektifan kepemimpinan tergantung pada kecocokan antara kepribadian, tugas, kekuasaan, sikap dan persepsi. Kepemimpinan situasional pada fenomena kepemimpinan difokuskan pada suatu situasi yang unik. Pemimpin perlu menyesuaikan gaya mereka dengan aspek-aspek kultural (Robbins, 2009). Seorang kepala desa harus bisa menyesuaikan gaya kepemimpinannya dengan budaya Tri Hita Karana yang dianut oleh masyarakat desa di Bali. Kepala desa sebagai pemimpin formal di desa merupakan administrator pembangunan mempunyai peranan yang sangat penting dalam menggerakkan partisipasi masyarakat untuk ikut aktif dalam kegiatan pembangunan desa (Sukijan, 2012).

Penelitian Gunawan (2009) menunjukkan hasil bahwa terdapat pengaruh positif dan signifikan antara kepemimpinan dan kinerja organisasi. Subroto 
(2009), Kamaliah (2011), Dharmanegara dkk., (2013), dan Diputra (2012) juga menyatakan kepemimpinan transformasional berpengaruh signifikan pada akuntabilitas kinerja.

$\mathrm{H}_{3}$ : Kepemimpinan berpengaruh positif pada akuntabilitas pengelolaan dana desa

Teori kualitas menyatakan bahwa agar sesuai dengan yang distandarkan, suatu produk atau jasa harus dikerjakan oleh orang yang memiliki skills tinggi (kompeten) dan behavior yang baik. Penelitian Zirman dkk., (2010) menyebutkan kompetensi sumber daya manusia berpengaruh terhadap akuntabilitas kinerja instansi pemerintah. Berbeda dengan penelitian Rofika dan Ardianto (2014), Saputra (2010) membuktikan bahwa kompetensi SDM tidak berpengaruh pada akuntabilitas kinerja keuangan pemerintah.

Manusia mempunyai kewajiban untuk mempertahankan keseimbangan alam semesta antara lain dalam bentuk perilaku prososial (Sarwono, 2002). Perilaku prososial terjadi pada tingkat kedekatan antara individu. Posisi formal seseorang dalam suatu organisasi atau komunitas memengaruhi kemurahan hati seseorang terhadap anggota dalam sebuah kelompok (Baldassarri dan Grossman, 2013). Teori perilaku sosial menjelaskan prosocial behavior adalah perilaku menolong orang lain tanpa mengharapkan imbalan sebagai rasa tanggung jawabnya dalam bersosialisasi dengan masyarakat. Pernyataa tersebut sesuai teori norma tanggung jawab sosial (Sear, 1991). Aparat pemerintah desa pada umumnya berasal dari desanya sendiri. Seseorang dalam berbagai budaya lebih senang menolong orang lain yang termasuk dalam kelompoknya (in-group) dibandingkan dengan seseorang yang bukan dari kelompoknya (outgroup) (Brewer dan Brown 1998, dalam Widyarini, 2005). Peneliti menduga bahwa faktor perilaku aparat pemerintah desa menolong orang lain tanpa mengharapkan imbalan memegang peranan penting terhadap keberhasilan pengelolaan keuangan desa. Prosocial behavior yang dimiliki oleh aparat pemerintah desa akan memperkuat hubungan antara kompetensi sumber daya manusia dan akuntabilitas pengelolaan dana desa.

$\mathrm{H}_{4}$ : Prosocial behavior memperkuat pengaruh kompetensi sumber daya manusia pada akuntabilitas pengelolaan dana desa.

Selain dengan adanya akuntabilitas dari organisasi pemerintah itu sendiri, masyarakat juga harus turut serta berperan aktif dalam mengatasi masalah di daerahnya yakni dengan berpartisipasi aktif dalam kegiatan pembangunan. Program pembangunan desa perlu diarahkan pada upaya pemberdayaan masyarakat. Forum musyawarah desa dapat dijadikan media dalam pengambilan keputusan yang menyangkut urusan strategis dan hajat hidup masyarakatnya (ugm.ac.id).

Penelitian Raharja dkk., (2015), Lestari (2014), Retnaningtyas (2016), mendapatkan hasil bahwa partisipasi tidak berpengaruh terhadap akuntabilitas kinerja keuangan SKPD. Penelitian Werimon (2005) mendapatkan hasil bahwa partisipasi masyarakat berpengaruh terhadap pengelolaan anggaran dengan pengawasan keuangan daerah (APBD). Suarmanayasa (2017) mendapatkan hasil partisipasi masyarakat mempunyai pengaruh terhadap keberhasilan pembangunan desa.

Meningkatnya partisipasi masyarakat dalam pembangunan merupakan perwujudan dari perubahan sikap dan perilaku (Soetomo, 2006). Aparat pemerintah desa yang mempunyai perilaku prososial yang tinggi artinya menolong orang lain tanpa mengharapkan imbalan dengan rasa tulus akan melaksanakan tugas sesuai dengan tanggung jawabnya sehingga meningkatkan partisipasi masyarakat.

$\mathrm{H}_{5}$ : Prosocial behavior memperkuat pengaruh partisipasi masyarakat pada akuntabilitas pengelolaan dana desa.

Kepemimpinan adalah cara seorang pemimpin yang mempunyai kekuasaan memengaruhi perilaku bawahan agar mau bekerja sama dan bekerja secara produktif untuk mencapai tujuan organisasi (Hasibuan ,2013). Pembangunan dapat terlaksana dengan baik jika ada kerjasama antara pemimpin dengan masyarakat yang dipimpinnya. Kepala desa sangat berperan dalam pembangunan desa karena merupakan pemimpin formal yang memiliki tugas dan kewajiban dalam menyelenggarakan urusan pembangunan. Terdapat hubungan positif antara kepemimpinan kepala desa dan partisipasi masyarakat dalam pembangunan (Djaenuri, 2010)

Penelitian Wulandari (2013) mendapatkan kepemimpinan berpengaruh positif pada tingkat keberhasilan proyek PNPM Mandiri Pedesaan. Sejalan dengan penelitian tersebut Arifin (2007) menyatakan bahwa kepemimpinan kepala desa mempunyai pengaruh yang kuat terhadap keberhasilan pembangunan desa. Berbeda dengan penelitian Supartha (2006) dan Sapta (2017) menyatakan bahwa tidak ada pengaruh kepemimpinan terhadap kinerja organisasi. 
Posisi sosial yang menunjukkan peran dalam pemerintahan desa adalah peran dari seorang kepala desa dalam pengelolaan dana desa. Teori peran menjelaskan perilaku sosial dalam konteks fungsi dan posisi sosial dalam masyarakat. Diduga bahwa prosocial behavior akan memperkuat pengaruh kepemimpinan pada akuntabilitas pengelolaan dana desa.

$\mathrm{H}_{6}$ : Prosocial behavior memperkuat pengaruh kepemimpinan pada akuntabilitas pengelolaan dana desa.

\section{METODE PENELITIAN}

Kabupaten Karangasem Provinsi Bali menjadi lokasi penelitian mempunyai 8 kecamatan dan 75 desa. Populasi penelitian adalah aparat pemerintah desa yang terlibat dalam proses perencanaan dan pelaksanaan kegiatan desa yang bersumber dari dana desa. Aparat pemerintah desa meliputi kepala desa, sekretaris desa, dan kaur keuangan atau bendahara. Sampel penelitian ditentukan dengan cluster random sampling, sehingga diperoleh 48 responden dari 16 desa di 8 kecamatan. Data penelitian dikumpulkan dengan kuesioner. Kuesioner dibawa langsung kepada 48 responden di 16 desa di Kabupaten Karangasem. Sebanyak 45 kuesioner yang kembali digunakan sebagai data penelitian.

Variabel yang digunakan adalah variabel manifes, eksogen, dan endogen. Variabel manifes adalah indikator variabel yang nilainya didapatkan dari jawaban responden dalam kuesioner. Variabel eksogen adalah kompetensi sumber daya manusia, partisipasi masyarakat, kepemimpinan, dan variabel moderating prosocial behavior. Kompetensi sumber daya manusia diukur dengan indikatorindikator yang dikembangkan oleh Irwan (2011). Indikator yang digunakan adalah pengetahuan, keterampilan, dan perilaku. Variabel partisipasi masyarakat diukur dengan menggunakan indikator yang dikembangkan oleh Werimon (2005) yaitu pemberian informasi, konsultasi, kemitraan, pendelegasian, keaktifan warga, keterlibatan dalam pengambilan keputusan, menyumbang tenaga, uang dan material. Variabel kepemimpinan pada penelitian ini didefinisikan dalam konteks Asta Dasa Paramething Prabu diukur dengan menggunakan indikator dimensi spriritual, moral dan manajerial, yang diadopsi dari penelitian Surya (2014). Variabel moderating prosocial behavior diukur dengan menggunakan indikator menolong orang lain, berbagi dan menyumbang, bekerja sama, sikap empati, dan kejujuran.
Variabel endogen adalah akuntabilitas pengelolaan dana desa dalam konteks budaya Tri Hita Karana. Varibel endogen dioperasionalkan dengan menggunakan indikator-indikator yang dikembangkan oleh Ariyanto (2014). Indikator yang digunakan adalah parahyangan, pawongan dan palemahan. Keseluruhan indikator tersaji ke dalam 11 pernyataan kuesioner.

Indikator-indikator atau instrument pertanyaaan atau pernyataan pada penelitian ini diukur dengan point 5 skala Likert. Teknik analisis data yang digunakan adalah analisis partial least squares (PLS) dengan bantuan SmartPLS 3.2.6. Pada tahap awal dilakukan pengujian instrumen untuk menguji validitas dan reliabilitas kuesioner. Langkah-langkah analisis data dengan menggunakan SmartPLS 3.2.6. adalah (1) Merancang model sturktural, (2) Merancang model pengukuran; (3) Mengonstruksi diagram jalur, (4) Konversi diagram jalur ke sistem persamaan; (5) Estimasi koefisien jalur, loading dan weight; (6) Evaluasi goodness of fit, (7) Pengujian hipotesis.

\section{HASIL DAN PEMBAHASAN}

Pilot test kepada 32 mahasiswa STAR BPKP Magister Akuntansi Universitas Udayana telah dilakukan untuk menguji validitas dan reliabilitas instrumen yang digunakan dalam penelitian. Tahap pertama uji validitas menunjukkan hasil bahwa indikator PM4 tidak valid karena memiliki nilai loading factor $<0,6$. Nilai cross loading didapatkan lebih rendah dari blok indikator variabel laten lain yang diukur. Oleh sebab itu, indikator Partisipasi Masyarakat (PM4) dikeluarkan dari model. Pengujian ulang mendapatkan kesimpulan bahwa seluruh item pernyataan kuesioner adalah valid. Nilai cronbach's alpha dan composite reliability > 0,6 untuk seluruh konstruk, sehingga seluruh indikator konstruk dalam kuesioner adalah reliabel.

Statistik deskriptif disajikan dalam rangka memberikan gambaran tentang persepsi responden terhadap pernyataan atas konstruk penelitian yang digunakan. Persepsi responden diukur dengan menggunakan kriteria three-box method, yaitu nilai skor 1,0 s.d. 2,33 dikategorikan " rendah", nilai skor 2,34 s.d. 3,67 dikategorikan "sedang", dan nilai skor 3,68 s.d. 5,00 dikategorikan "tinggi" (Ferdinand, 2006:292). Berdasarkan kriteria three-box method, indeks persepsi responden terhadap konstruk penelitian ditentukan.

Hasil analisis Tabel 1 menjelaskan bahwa persepsi responden tentang variabel kompetensi sumber daya, partisipasi masyarakat, kepemimpinan, perilaku prososial dan akuntabilitas pengelolaan dana desa dalam konteks budaya THK termasuk klasifikasi tinggi. 
Tabel 1.

Hasil Statistik Deskriptif

\begin{tabular}{lccccc}
\hline \multicolumn{1}{c}{ Konstruk } & N & Maksimum & Minimum & Mean & Kategori \\
\hline Kompetensi SDM & 45 & 5 & 2 & 4,14 & Tinggi \\
Partisipasi Masyarakat & 45 & 5 & 3 & 4,30 & Tinggi \\
Kepemimpinan & 45 & 5 & 1 & 4,24 & Tinggi \\
Prosocial behavior & 45 & 5 & 1 & 4,27 & Tinggi \\
Akuntabilitas Dana Desa & 45 & 5 & 1 & 4,41 & Tinggi \\
Sumber : Data diolah, 2017 & & & & &
\end{tabular}

Uji validitas konvergen Tabel 2 menghasilkan nilai outer loading factor $>0,6$ untuk seluruh indikator konstruk dan nilai Average Variance Extracted (AVE) semua konstruk diatas > 0,50, sehingga memenuhi persyaratan validitas konvergen.
Setiap indikator konstruk memiliki nilai cros loadings $>0,6$ dan mengumpul pada konstruk yang telah ditetapkan, sehingga memenuhi uji validitas diskriminan. Dengan demikian data yang digunakan dalam penelitian adalah valid.

Tabel 2.

Hasil Estimasi Algoritma

\begin{tabular}{lcccc}
\hline \multicolumn{1}{c}{ Konstruk } & AVE & $\begin{array}{c}\text { Composite } \\
\text { Reliability }\end{array}$ & $\begin{array}{c}\text { Cronbach's } \\
\text { Alpha }\end{array}$ & R Square \\
\hline Kompetensi SDM & 0,633 & 0,837 & 0,708 & \\
Partisipasi Masyarakat & 0,541 & 0,875 & 0,829 & \\
Kepemimpinan & 0,797 & 0,922 & 0,872 & \\
Prosocial behavior & 0,583 & 0,874 & 0,818 & 0,683 \\
Akuntabilitas Dana Desa & 0,752 & 0,901 & 0,835 & 0,835 \\
\hline
\end{tabular}

Sumber : Data diolah, 2017

Semua indikator konstruk reliabel. Tabel 2 menunjukkan nilai Composite Reliability yang dihasilkan semua konstruk sangat baik yaitu diatas $>0,70$. Nilai Cronbach Alpha menunjukkan setiap item pernyataan lebih besar $>0,70$. Hal ini mengindikasikan bahwa jawaban responden terhadap item-item pernyataan adalah konsisten dan reliabel.
Pengujian Goodness of Fit mendapatkan nilai $\mathrm{R}$ square sebesar 0,683. Hal ini menunjukkan bahwa kekuatan model baik $\left(\mathrm{R}^{2}>0,67\right)$. Artinya, variabelvariabel yang dimasukkan dalam model dapat menjelaskan 68,3 persen varian akuntabilitas dana desa, sedangkan sisanya 31,79 persen varian dipengaruhi oleh faktor-faktor lain di luar model.

Tabel 3.

Hasil Pengujian Hipotesis

\begin{tabular}{lrrrr}
\hline \multicolumn{1}{c}{ Uraian } & $\begin{array}{l}\text { Original } \\
\text { Sample }\end{array}$ & T Statistics & P Values & $\begin{array}{c}\text { Jenis } \\
\text { Moderasi }\end{array}$ \\
\hline SDM -> AKB & 0,295 & 2,030 & 0,043 & \\
PM -> AKB & 0,600 & 2,769 & 0,006 & \\
K -> AKB & $-0,425$ & 1,749 & 0,081 & \\
SDM*PP -> AKB & $-0,290$ & 2,382 & 0,018 & quasi \\
PM*PP -> AKB & 0,459 & 2,122 & 0,034 & quasi \\
K*PP -> AKB & $-0,418$ & 1,685 & 0,093 & predictor \\
Keterangan: SDM=Kompetensi Sumber Daya Manusia.PM=Partisipasi Masyarakat. K=Kepemimpinan. & \\
\multicolumn{4}{l}{ Sumber $:$ Data diolah, 2017 }
\end{tabular}


Hasil pengujian hipotesis Tabel 3. Signifikansi dari model prediksi dalam pengujian model struktural dapat dilihat dari nilai $P$ value. Hasil pengujian empiris menunjukkan $\mathrm{H}_{1}$ didukung yaitu kompetensi sumber daya manusia berpengaruh positif pada akuntabilitas pengelolaan dana desa. Semakin kompeten aparat pemerintah desa, semakin mampu aparat pemerintah desa mengelola dana desa secara akuntabel. Hasil penelitian mendukung hasil penelitiannya Fitriyah (2013) dan Santoso (2016) yang membuktikan bahwa kompetensi sumber daya manusia berpengaruh signifikan pada akuntabilitas pengelolaan keuangan pemerintah daerah.

Hasil analisis deskriptif indikator untuk konstruk kompetensi sumber daya manusia memperlihatkan pernyataan-pernyataan dalam indikator perilaku (SDM3) dipersepsikan tinggi oleh responden dengan nilai mean sekitar 4,0. Pernyataan selalu menolak segala bentuk suap yang berhubungan dengan tugas dan tanggung jawab (SDM3.2), dipersepsikan paling tinggi dengan nilai mean 4,51. Oleh karena itu, dapat dinyatakan bahwa responden menekankan lebih tinggi atas perilaku tidak menerima suap dalam melaksanakan pengelolaan dana desa. Perilaku sumber daya manusia tersebut menunjukkan kompetensi aparat pemerintah desa yang baik, sehingga menunjang akuntabilitas pengelolaan dana. Argumen tersebut didukung oleh penelitian Fajri dkk. (2014) yang menyatakan bahwa untuk mengelola alokasi dana desa diperlukan aparat pemerintah yang memiliki kemampuan dan tanggung jawab untuk mengelola dana tersebut. Hal itu dibuktikan dengan cara mematuhi dan mengikuti tahapan serta ketentuan dan peraturan yang berlaku.

Sejalan dengan yang dikemukan Putra (2000) tentang dimensi parahyangan dalam budaya THK, mengandung arti bahwa seorang karyawan memiliki keyakinan atas keberhasilan yang dicapai bukanlah semata-mata dari kemampuan dan kerja keras mereka melainkan karena kehendak Tuhan. Dikatakan juga bahwa pendekatan diri kepada Tuhan membuat mereka bisa berpikir tenang dan religius. Situasi ini dapat meningkatkan kemampuan mereka untuk mengendalikan diri terhadap perilaku yang negatif yang merugikan pihak lain.

Data empiris juga menunjukkan bahwa responden menekankan memiliki keterampilan (SDM2) yaitu mampu bekerja sama dengan rekan kerja dalam mengelola dana desa. Argumen tersebut sejalan dengan Alimbudiono dkk., (2004) yang mengemukakan kompetensi sumber daya manusia dapat dilihat dari latar belakang pendidikan dan pelatihan serta keterampilan dalam melaksanakan tugas. Sedangkan level of responsibility digunakan untuk menilai kualitas dan kinerjanya dalam melaksanakan tugas, termasuk akuntansi. Indikator pengetahuan (SDM1) juga dipersepsikan tinggi oleh responden dengan nilai mean 4,08. Oleh karena itu, dapat disimpulkan bahwa aparat pemerintah desa memahami tugas pokok, fungsi dan uraian tugas, dan proses penganggaran pengelolaan dana desa dengan baik. Hal ini sejalan dengan yang dinyatakan oleh Farazman (2009) bahwa kemampuan administratis merupakan core of govermant dan komponen penting dalam melaksanakan pemerintahan.

Hasil penelitian menunjukkan bahwa kompetensi sumber daya manusia berpengaruh pada akuntabilitas pengelolaan dana desa dalam konteks budaya Tri Hita Karana. Akuntabilitas dalam konteks budaya THK dimaksudkan bahwa pertanggungjawaban pengelolaan dana desa dilakukan secara menyeluruh, tidak saja pertanggungjawaban keuangan secara formal, tetapi juga pertanggungjawaban kepada Tuhan dan lingkungan. Sejalan dengan hal tersebut Wiana (2007:10) mengungkapkan bahwa untuk menyukseskan tujuan hidup perlu dibangun sikap hidup yang seimbang antara bakti kepada Tuhan, mengabdi kepada sesama manusia, dan memelihara kesejahteraan lingkungan.

Bukti empiris ini memiliki implikasi bahwa pertanggungjawaban pengelolaan dana desa secara menyeluruh (dalam konteks Tri Hita Karana) dapat dicapai ketika individu memiliki kompetensi yang mencerminkan nilai dan norma yang terdapat dalam ajaran agama serta spirit kerja dipandang sebagai pengorbanan dan pengabdian. Semakin tinggi kompetensi aparat pemerintah desa akan menghasilkan pengelolaan dana desa yang memiliki kebijakan dan program pemberdayaan masyarakat yang mengarah pada kesejahteraan masyarakat dan pelestarian alam lingkungannya.

Hasil pengujian menunjukkan $\mathrm{H}_{2}$ didukung bahwa partisipasi masyarakat berpengaruh positif pada akuntabilitas pengelolaan dana desa. Semakin baik partisipasi masyarakat, semakin akuntabel pengelolaan dana desa. Hasil penelitian mendukung hasil penelitian Listya (2011), Wulandari (2013), dan Kurniawan (2011). Penelitian Arifin (2007) juga menyatakan bahwa partisipasi masyarakat berpengaruh terhadap keberhasilan pembangunan desa.

Penjelasan tersebut sejalan dengan Umboh (2004) menyatakan bahwa perencanaan pembanguna desa ideal dilakukan oleh masyarakat desa secara partisipatif karena masyarakat desalah yang jauh lebih mengetahui dan mengerti masalah di desa dan potensi yang bisa digali demi kemajuan desanya. Masyarakat 
desa diharapkan dapat berpartisipasi dalam perencanaan APBDes, mengetahui secara transparan kondisi keuangan desa, dan pemerintah desa wajib mengelola keuangan desa secara bertanggungjawab (Hanifah dan Praptoyo, 2015).

Hasil analisis deskriptif memperlihatkan bahwa semua indikator partisipasi masyarakat dipersepsikan tinggi oleh responden dengan nilai mean sekitar 4,0. Indikator keterlibatan dalam pengambilan keputusan dipersepsikan paling tinggi dengan nilai mean 4,44. Hal ini menunjukkan bahwa responden menganggap sangat penting aspirasi masyarakat dalam penyusunan anggaran dana desa. Indikator selanjutnya adalah keaktifan warga (PM5). Indikator ketiga yang dipersepsikan tinggi adalah konsultasi (PM2), dan pemberian informasi (PM1).

Sesuai dengan yang dikemukakan Suarmanayasa (2017), partisipasi merupakan keterlibatan masyarakat dalam pembangunan yang meliputi kegiatan perencanaan dan pelaksanan yang dikerjakan oleh masyarakat lokal. Keikutsertaan masyarakat menjadi ukuran tingkat partisipasi rakyat. Kemampuan mereka dalam pembangunan ditunjukkan dari seberapa besar kemampuan mereka untuk menentukan nasibnya sendiri. Blair (2000:21) juga mengemukakan bahwa hal utama dari desentralisasi adalah membangun partisipasi dan tanggung jawab kepada pemerintah lokal atau daerah. Pada dasarnya masyarakat dapat berperan aktif dari tahap penyusunan rencana pembangunan. Partisipasi masyarakat dapat memberikan alternatif rencana dan usulan kepada pemerintah. Sejalan dengan Eko dkk. (2016), masyarakat desa harus dilibatkan dalam pengelolaan dana desa. Masyarakat desa mempunyai wewenang dalam mengambil keputusan dalam pembangunan desa. Prioritas usulan penggunaan dana desa adalah berasal dari masyarakat desa, dibahas dan diputuskan oleh masyarakat desa.

Akuntabilitas pengelolaan dana desa dalam konteks budaya Tri Hita Karana mengandung makna bahwa pertanggungjawaban secara menyeluruh menyangkut hubungan harmonis manusia dengan Tuhan, hubungan harmonis dengan sesama dan hubungan harmonis dengan alam lingkungan. Prinsip Tri Hita Karana ini telah menjadi dasar tradisi budaya masyarakat Bali. Sujana dkk (2015) menyatakan bahwa Tuhan merupakan prinsipal tertinggi, pencipta dan pemberi kehidupan bagi semua makhluk yang ada di alam semesta. Manusia mempunyai kewajiban untuk bersyukur dan berterimakasih atas kehidupan dan sumber penghidupan yang diberikan Tuhan. Bentuk syukur dan terima kasih ini ditunjukkan oleh manusia melalui bentuk kerja yang bertujuan untuk kesejahteraan manusia dan alam lingkungan. Partisipasi masyarakat mengindikasikan kesadaran masyarakat bahwa berpartisipasi dalam mengelola dana desa merupakan suatu bentuk syukur dan terima kasih serta pengabdian diri kepada Tuhan, manusia, dan alam lingkungannya.

Hipotesis pengujian empiris $\mathrm{H}_{3}$ tidak didukung yaitu kepemimpinan tidak berpengaruh pada akuntabilitas pengelolaan dana desa. Bukti empiris ini konsisten dengan penelitian Supartha (2006) dan Sapta (2017). Hal ini bermakna bahwa nilai kepemimpinan tidak berpengaruh pada akuntabilitas pengelolaan dana desa dalam konteks budaya Tri Hita Karana. Artinya semakin baik nilai kepemimpinan tidak mampu memengaruhi akuntabilitas pengelolaan dana desa. Hasil penelitian memberi makna bahwa meningkatnya nilai kepemimpinan tidak berpengaruh secara positif pada akuntabilitas pengelolaan dana desa.

Hal ini dapat terjadi karena pengelolaan dana desa dilaksanakan oleh Tim Pelaksana Teknis Pengelola Keuangan Desa, yaitu perangkat desa yang terdiri dari kepala desa, sekretaris desa, kepala urusan, dan bendahara. Setiap perangkat desa mempunyai kewenangan tugas dan tanggungjawab yang berbeda-beda. Hal ini dilakukan guna menjamin pengendalian keuangan tidak berada dalam satu tangan, tetapi berada dalam satu tim sehingga dapat menghindari terjadinya penyimpangan (Eko dkk., 2016). Hal ini menyebabkan peran nilai kepemimpinan sangat kecil bahkan diabaikan oleh aparat pemerintah desa.

Analisis deskriptif kontruk akuntabilitas pengelolaan dana desa dalam konteks budaya Tri Hita Karana menunjukkan pernyataan hukum karmaphala (hasil perbuatan) menjadi pegangan dalam melakukan pengelolaan dana desa dipersepsikan paling tinggi oleh responden dalam membentuk dimensi parahyangan dengan nilai mean 4,49. Hal ini menunjukkan responden menekankan tinggi hukum karmaphala sebagai perwujudan akuntabilitas kepada Tuhan.

Hasil penelitian menunjukkan bahwa responden mempersepsikan baik kepemimpinan untuk meningkatkan akuntabilitas pengelolaan dana desa. Mereka sangat menyadari nilai kepemimpinan sebagaimana konsep yang ada di dalam Agama Hindu yakni Asta Dasa Parameting Prabu, namun tidak serta merta nilai-nilai ini dilaksanakan oleh aparat pemerintah desa. Budaya THK sudah menjadi tradisi masyarakat desa di Bali. Aparat pemerintah desa tanpa diperintah atau dinasehati oleh pemimpinannya secara otomatis melaksanakan 
kewajiban dan tanggung jawabnya karena ketaatannya pada tradisi yang ada. Sejalan dengan penelitian Sapta (2017), bahwa pengelola subak di Bali yang memegang teguh konsep Tri Hita Karana akan melaksanakan tugas dan tanggung jawabnya karena kepatuhan pada tradisi yang dianutnya. Sebagaimana diungkapkan oleh Robbins (2009) bahwa kepemimpinan memiliki batas-batas artinya para pemimpin perlu menyesuaikan gaya mereka dengan aspek-aspek kultural. Nilai kepemimpinan tidak berpengaruh jika diterapkan pada individu yang memegang teguh konsep budaya Tri Hita Karana. Seorang aparat desa yang taat akan tugas dan kewajibannya akan memegang teguh prinsip hukum karma phala dan menganggap bekerja adalah bakti kepada Tuhan.

Hasil uji $\mathrm{H}_{4}$ menunjukan tidak ditemukan bukti empiris bahwa Prosocial behavior memperkuat pengaruh kompetensi sumber daya manusia pada akuntabilitas pengelolaan dana desa. Hasil pengujian menunjukan sebaliknya, bahwa perilaku prosocial behavior memperlemah pengaruh kompetensi sumber daya manusia pada akuntabilitas pengelolaan dana desa dengan nilai estimasi koefisien bertanda negatif. Artinya, semakin besar prosocial behavior yang dimiliki oleh aparat pemerintah desa, justru semakin kecil pengaruh hubungan kompetensi sumber daya manusia pada akuntabilitas pengelolaan dana desa.

Kehidupan desa adat di Bali, perilaku prososial (ngayah) masyarakatnya tercermin dalam berbagai kegiatan (kematian, menyelenggarakan pesta, dan pertanian) yang dilakukan secara bekerja sama sebagai bentuk pengabdian (yadnya) dalam membantu meringankan beban orang lain. Hal ini sesuai teori norma tanggung jawab sosial (social responsibility norm) yang dikemukakan (Sear et. al., 1991), dalam hidup bermasyarakat setiap orang memiliki kewajiban untuk menolong sesama sebagai wujud tanggung jawab Norma ini mengharuskan setiap orang untuk memberikan pertolongan karena ajaran agama dan aturan moral yang berlaku di masyarakat.

Bukti empiris menunjukkan bahwa responden dengan prosocial behavior yang tinggi, justru semakin memperlemah pengaruh kompetensi sumber daya manusia pada akuntabilitas pengelolaan dana desa. Hal ini disebabkan oleh responden selaku aparat pemerintah desa lebih mengutamakan kegiatan sosial kemasyarakatan, sehingga kegiatan pengelolaan dana desa menjadi terganggu. Dengan melaksanakan kegiatan di luar tugas dan fungsi pokok sebagai aparat pemerintah desa menyebabkan menurunnya akuntabilitas pengelolaan dana desa.
Hasil pengujian memperlihatkan bahwa koefisien variabel moderasi prosocial behavior memperlihatkan hasil yang signifikan dan interaksinya dengan variabel eksogen kompetensi sumber daya manusia memperlihatkan hasil yang juga signifikan. Dalam Solimun (2010) dijelaskan bahwa jenis variabel pemoderasi seperti ini disebut sebagai quasi moderasi. Artinya bahwa variabel moderasi perilaku prososial memoderasi hubungan antara variabel kompetensi sumber daya manusia pada akuntabilitas pengelolaan dana desa, sekaligus sebagai variabel prediktor pada akuntabilitas pengelolaan dana desa.

Hasil uji $\mathrm{H}_{5}$ menunjukan bukti empiris bahwa prosocial behavior memperkuat pengaruh partisipasi masyarakat pada akuntabilitas pengelolaan dana desa. Nilai estimasi koefisien beta bertanda positif mengindikasikan hubungan positif (memperkuat). Artinya, semakin besar prosocial behavior yang dimiliki oleh aparat pemerintah desa, semakin besar pengaruh partisipasi masyarakat pada akuntabilitas pengelolaan dana desa.

Indikator berbagi dan menyumbang, dan indikator bekerja sama dipersepsikan paling tinggi oleh responden dalam membentuk perilaku prososial. Hasil dari analisis deskriptif indikator bermakna bahwa responden mempersepsikan aparat pemerintah desa melaksanakan tugas dan tanggung jawabnya dengan baik yang dilakukan dengan saling menghargai pendapat orang lain dan bekerja sama dalam melaksanakan pekerjaan. Hal ini juga tercermin dari jawaban terbuka dalam pernyataan kuesioner yaitu dalam melaksanakan pengelolaan dana desa responden mengharapkan peningkatan peran serta dari masyarakat desa, sehingga pengelolaan dana desa dapat di pertanggungjawabkan.

Dimensi inti dari modal sosial terletak pada kemampuan masyarakat untuk bekerja sama guna mencapai tujuan bersama (Hasbullah, 2006). Kerja sama tersebut diwarnai oleh suatu pola imbal balik yang saling menguntungkan serta dibangun atas suatu kepercayaan yang ditopang oleh norma-norma dan nilai sosial yang positif dan kuat. Pernyataan tersebut juga sesuai dengan teori peran (Myers, 2002) menyatakan bahwa individu-individu yang berada dalam suatu posisi atau fungsi sosial tertentu memiliki keharusan untuk berperilaku tertentu sesuai norma yang dianutnya.

Wiana (2007) menjelaskan bahwa ngayah merupakan perwujudan bakti kepada Tuhan, yaitu mengabdi dalam bentuk kegiatan yang dilakukan dengan tulus ikhlas. Modal sosial tersebut akan maksimal jika didukung oleh sikap partisipatif, saling memperhatikan, tolong menolong, saling mempercayai 
serta diperkuat oleh nilai-nilai dan norma yang mendukungnya (Suarmanayasa, 2017).

Sejalan dengan Wirajaya (2014) yang menjelaskan bahwa salah satu bentuk pengabdian atau yadnya masyarakat desa di Bali adalah dengan bekerja untuk masyarakat yang hasilnya diyakini akan diperoleh pada kehidupan berikut (reinkarnasi). Perilaku prososial yang tinggi memperkuat pengaruh partisipasi masyarakat pada akuntabilitas pengelolaan dana desa dalam konteks budaya Tri Hita Karana. Hal ini disebabkan oleh responden memiliki perilaku bekerja sama yang dibangun atas suatu kepercayaan dan ditopang oleh norma-norma dan nilai sosial yang positif dan kuat. Masyarakat desa menganggap ngayah merupakan perwujudan bakti kepada Tuhan, yang dilakukan melalui kegiatan-kegiatan partisipatif pengelolaan dana desa dan dilaksanakan secara tulus ikhlas.

Berdasarkan hasil uji koefisien variabel moderasi, jenis variabel prososial behavior dalam hubungan ini disebut sebagai quasi moderasi. Artinya, variabel moderasi perilaku prososial memoderasi hubungan antara variabel partisipasi masyarakat dan akuntabilitas pengelolaan dana desa, sekaligus sebagai variabel prediktor pada akuntabilitas pengelolaan dana desa.

Hasil uji $\mathrm{H}_{6}$ tidak menemukan bukti empiris bahwa prosocial behavior memperkuat pengaruh kepemimpinan pada akuntabilitas pengelolaan dana desa. Artinya, prosocial behavior tidak memengaruhi tinggi rendahnya pengaruh variabel kepemimpinan pada variabel akuntabilitas pengelolaan dana desa. Prosocial behavior tidak memperkuat atau memperlemah pengaruh kepemimpinan pada akuntabilitas pengelolaan dana desa. Hipotesisi penelitian prososial behavior memperkuat hubungan pengaruh kepemimpinan pada akuntabilitas pengelolaan dana desa, dibangun berdasarkan teori peran. Teori peran memberikan penelaahan pada perilaku sosial dalam penekanan pada konteks sosial, fungsi, dan posisi sosial yang terdapat dalam masyarakat. Perilaku sosial seseorang merupakan aktualisasi dari suatu peran tertentu. Posisi sosial yang menunjukkan peran dalam pemerintahan desa adalah peran dari seorang aparat pemerintah desa.

Hasil pengujian memperlihatkan bahwa koefisien variabel moderasi prosocial behavior memperlihatkan hasil yang signifikan tetapi interaksinya dengan variabel eksogen kepemimpinan memperlihatkan hasil yang tidak signifikan. Jenis variabel pemoderasi seperti ini disebut sebagai predictor moderasi. Prediktor moderasi artinya bahwa variabel moderasi perilaku prososial hanya berperan sebagai variabel prediktor dalam model hubungan kepemimpinan pada akuntabilitas pengelolaan dana desa dalam konteks budaya Tri Hita Karana.

\section{SIMPULAN}

Berdasarkan hasil pengujian empiris dan pembahasan dapat disimpulkan bahwa kompetensi sumber daya manusia berpengaruh positif pada akuntabilitas pengelolaan dana desa dalam konteks budaya THK. Semakin tinggi kompetensi aparat pemerintah desa akan menghasilkan pengelolaan dana desa yang memiliki kebijakan dan program pemberdayaan masyarakat yang mengarah pada kesejahteraan masyarakat dan pelestarian alam lingkungannya. Partisipasi masyarakat berpengaruh positif pada akuntabilitas pengelolaan dana desa dalam konteks budaya THK. Partisipasi masyarakat mengindikasikan kesadaran masyarakat bahwa berpartisipasi dalam mengelola dana desa merupakan suatu bentuk syukur dan terima kasih serta pengabdian diri kepada Tuhan, manusia, dan alam lingkungannya. Kepemimpinan tidak ditemukan bukti empiris berpengaruh pada akuntabilitas pengelolaan dana desa dalam kontek budaya THK. Hal ini bermakna bahwa tidak ada pengaruh kepemimpinan pada akuntabilitas pengelolaan dana desa. Hal ini dapat terjadi karena pengelolaan dana desa dilaksanakan oleh Tim Pelaksana Teknis Pengelola Keuangan Desa. Masing-masing anggota tim mempunyai fungsi yang penting dalam pengelolaan dana desa sehingga peran nilai kepemimpinan sangat kecil bahkan diabaikan oleh aparat pemerintah desa. Nilai kepemimpinan tidak berpengaruh jika diterapkan pada individu yang memegang teguh konsep budaya THK. Seorang aparat desa yang taat akan tugas dan kewajibannya akan memegang teguh prinsip hukum karmaphala, dan menganggap bekerja adalah bakti kepada Tuhan. Prosocial behavior memperlemah pengaruh kompetensi pada akuntabilitas pengelolaan dana desa. Semakin tinggi prosocial behavior aparat pemerintah desa, justru semakin kecil pengaruh kompetensi pada akuntabilitas pengelolaan dana desa. Perilaku prososial yang tinggi menyebabkan aparat pemerintah desa lebih mengutamakan kegiatan sosial kemasyarakatan. Dengan melaksanakan kegiatan diluar tugas pokok dan fungsinya sebagai aparat pemerintah desa menyebabkan menurunnya akuntabilitas pengelolaan dana desa. Prosocial behavior memperkuat pengaruh partisipasi masyarakat pada akuntabilitas pengelolaan dana desa. Semakin besar prosocial 
behavior, justru semakin besar pengaruh partisipasi masyarakat pada akuntabilitas pengelolaan dana desa. Hal ini disebabkan karena responden memiliki perilaku bekerja sama yang dibangun atas suatu kepercayaan dan ditopang oleh norma-norma dan nilai sosial yang positif dan kuat. Masyarakat desa menganggap ngayah merupakan perwujudan bakti kepada Tuhan, yang dilakukan melalui kegiatankegiatan partisipatif pengelolaan dana desa dan dilaksanakan secara tulus ikhlas. Prosocial behavior tidak ditemukan bukti empiris memperkuat pengaruh kepemimpinan pada akuntabilitas pengelolaan dana desa.

Penelitian ini masih memiliki keterbatasan sehingga perlu disempurnakan. Pertama, penelitian dilakukan di pemerintahan desa Kabupaten Karangasem Bali yang berbasis kultur Tri Hita Karana, perlu dilakukan penelitian yang sama dibeberapa daerah lain yang sosial kulturnya sama maupun berbeda. Kedua, akuntabilitas pengelolaan dana desa dalam konteks budaya THK sangat kompleks. Hasil penelitian menunjukan bahwa kepemimpinan dalam konteks atau makna Asta Dasa Paramething Prabu tidak berpengaruh pada akuntabilitas pengelolaan dana desa. Kontradiksi hasil penelitian dapat dijadikan referensi peneliti selanjutnya dengan menggunakan konsep kepemimpinan yang berbeda. Perilaku prososial memperlemah hubungan kompetensi pada akuntabilitas pengelolaan dana desa. Dalam kehidupan bermasyarakat di Bali, khususnya di desadesa tidak bisa terlepas dari kegiatan sosial kemasyarakatan. Konsep pengabdian ini didasari oleh spirit Tri Hita Karana. Individu dituntut harus bisa berperan sebagai aparat pemerintah desa dan juga sebagai bagian dari masyarakat desa. Hal ini dapat menimbulkan konflik peran. Penelitian selanjutnya dapat meneliti variabel ambiguitas peran pada akuntabilitas pengelolaan dana desa. Berdasarkan jawaban terbuka dalam kuesioner, aparat pemerintah desa mengharapkan adanya pelatihan-pelatihan terkait pemanfaatan sistem informasi keuangan desa (siskeudes) dan pendampingan pengelolaan keuangan desa. Untuk itu pemerintah daerah disarankan agar mengoptimalkan peran instansi-instansi pendukung (Badan Pemberdayaan Masyarakat dan Pemerintahan Desa, Inspektorat Daerah, Camat) untuk memberikan pembinaan, pendampingan dan pengawasan pada pengelolaan dana desa.

\section{REFFERENSI}

Alimbudiono, Ria S., \& Fidelis A. A. (2004). Kesiapan Sumber Daya Manusia Sub Bagian
Akuntansi Pemerintah Daerah "XYZ" dan Kaitannya Dengan Pertanggungjawaban Keuangan Daerah Kepada Masyarakat: Renungan Bagi Akuntan Pendidik. Jurnal Akuntansi dan Keuangan Sektor Publik. 5(2), 18-30.

Arifin, S. (2007). Pengaruh Kepemimpinan Kepala Desa dan Partisipasi Masyarakat terhadap Keberhasilan Pembangunan Desa, Suatu Perspektif dari Segi Ketahanan Nasional: studi kasus Desa Nanga Tepuai Kecamatan Hulu Gurung Kabupaten Daerah Tingkat II Kapuas Hulu Propinsi Kalimantan Barat. Tesis. Jakarta: Universitas Indonesia.

Ariyanto, D. (2014). Does the Balinese Tri Hita Karana Culture Affect the Adoption and Usage of Information Technology Systems? Information and Knowledge Management. 1 (9), 150-160.

Aucoin, P., \& Heintzman, R. (2000). The Dialectics of Accountability for Performance in Public Management Reform. International Review of Administrative Sciences, 66(1), 45-55.

Baldassarri, D., \& Grossman, G. (2013). The Effect of Group Attachment and Sosial Position on Prosocial Behavior. Evidence from Lab-in-theField Experiments. PLoS One, 8(3), doi:10.1371/journal.pone.0058750

Barlan, A. Z. (2010). Pengaruh Pemimpin Lokal terhadap Keberhasilan Program Pembangunan (Studi Kasus : Pembangunan Saluran Irigasi dan Sarana Mandi Cuci Kakus (MCK) dalam Program Nasional Pemberdayaan Masyarakat (PNPM) Mandiri Perdesaan Desa Dramaga, Kecamatan Dramaga, Kabupaten Bogor. Tesis. Bogor: Institut Pertanian Bogor.

Bress, J. R. dan Martinko, M.J. (2015). The Effect of Intra-Personal and Environmental Factors on Accountability Acceptance and Their Consequences. Journal of Leadership, Accountability and Ethics, 12(1).

Blair, H. (2000). Participation and Accountability at the Periphery: Democratic Local Governance in Six Countries. World Development, 28(1), 21-39.

Brownell, P. (1982). The Role of Accounting Data in Performance Evaluation, Budgetary Participation, and Organizational Effectiveness, Journal of Accounting Research, 20, 12-27

Conyers, D. (1981). Decentralization for regional Development: a comparative Study of Tanzania, Zambia and Papua New Guinea. Public 
Administration and Development, 1(2), 107120

Crosby, P. B. (1989). Quality is Free. New American Library. New York.

Damayanti R. A. (2011). Hubungan Keagenan Pemerintahan Daerah Dalam Konteks Anggaran: Sebuah Agenda Rekonstruksi. Ekuitas. 15(2), $149-171$.

Dharmanegara, I. B. A., Sudarma, M., Noermijati, Solimun. (2013). Effect of Spiritual Intelligence and Asta Brata Leadership to the Culture of Tri Hita Karana and Employment Performance. IOSR Journal of Business and Management 11, 05-12.

Diansari, E. R. (2013). Evaluasi Akuntabilitas Kinerja Pengelola Alokasi Dana Desa (ADD) Kasus Seluruh Desa di Kecamatan Kledung Kabupaten Temanggung Tahun 2013 Tesis. Yogyakarta: Universitas Gajah Mada

Diputra, A. P. (2012). Pengaruh Manajemen Berbasis Kinerja, dan Kepemimpinan Transformasional terhadap Kinerja dan Akuntabilitas Pemerintah Daerah (Studi Empiris pada Pemerintah Kabupaten Sleman). Tesis. Yogyakarta: Universitas Gajah Mada

Djaenuri, M. A. (2010). Pengaruh Kepemimpinan Kepala Desa Terhadap Partisipasi Masyarakat Dalam Pembangunan Desa di Kecamatan Tambun. Tesis.Jakarta: Universitas Indonesia.

Eko, S., Putra S. A., Akhmadin, M., Suhirman, Prayitni, H., Suryana, N., \& Mustakim, Z. (2016). Dana Desa untuk Desa Membangun Indonesia (Tanya Jawab Seputar Dana Desa). Jakarta: Kementerian Desa, Pembangunan Daerah Tertinggal, dan Transmigrasi Republik Indonesia. Eisenhardt, K. M. (1989). Agency Theory: An Assessment and Review. The Academy of Management Review. 14(1), 57-74

Fajri R., Setyowati E., \& Siswidiyanto. (2014). Akuntabilitas Pemerintahan Pada Pengelolaan Alokasi Dana Desa (ADD) (studi pada Kantor Desa Ketindan, Kecamatan Lawang, Kabupaten Malang). Jurnal Administrasi Publik (JAP), 3(7), 1099-1104

Farazmand, A. (2009). Building Administrative Capacity for The Age of Rapid Globalization: A Modest Prescription for The Twenty-First Century. Public Administration Review, 69 (6), 1007 - 1020.

Ferdinand, A. (2006). Metode Penelitian Manajemen. Semarang: Badan Penerbit-Undip

Fitriyah, N. (2013). Pengaruh Kompetensi Sumber Daya Manusia Terhadap Kualitas Penyajian
Laporan Keuangan dan Implikasinya Terhadap Akuntabilitas Keuangan Pemerintah Daerah Kota Sukabumi. Tesis. Jakarta: Universitas Pendidikan Indonesia.

Gunawan, K. (2009). Pengaruh Budaya Organisasi, Kepuasan Kerja dan Motivasi Kerja terhadap Gaya Kepemimpinan dan Kinerja Organisasi (Studi pada Lembaga Perkreditan Desa (LPD) di Bali). Jurnal Aplikasi Manajemen, 7(2).

Hanifah,S.I dan Praptoyo, S. (2015). Akuntabilitas dan Transparansi Pertanggungjawaban Anggaran Pendapatan Belanja Desa (APBDes). Jurnal Ilmu \& Riset Akuntansi, 4(8).

Hasbullah, J. (2006). Sosial Kapital: Menuju Keunggulan Budaya Manusia Indonesia. Jakarta: MR.United Press

Hasibuan, M. (2013). Manajemen Sumber Daya Manusia. Cetakan Ketujuh Belas. Jakarta. Bumi Aksara.

Hughes, J., Sasse, G., \& Gordon, C. (2004). Conditionality and Compliance in The EU's Eastward Enlargement: Regional Policy and The Reform of Sub-national Government. Journal of Common Market Studies, 42(3), 523-551

Irwan, D. 2011. Pengaruh Penerapan Sistem Pengendalian Intern Pemerintah, Kompetensi Sumber Daya Manusia dan Penerapan Standar Akuntansi Pemerintahan terhadap Kualitas Laporan Keuangan Pemerintah Provinsi Sumatera Barat. Tesis. Yogyakarta:Universitas Gajah Mada.

Kamaliah. (2013). Pengaruh Gaya Kepemimpinan, Budaya Organisasi, dan Motivasi terhadap Kinerja Akuntan Pemerintah (Studi Empiris Pada Akuntan BPKP), Jurnal Akuntansi dan Manajemen Fakultas Ekonomi Universitas Riau.

Karauwan, R. O. (2013). Tinjauan Tentang Perilaku Kepemimpinan Kepala Desa Dalam Pelaksanaan Pembangunan di Desa Tounelet Kecamatan Kakas Kabupaten Minahasa.

Kurniawan, A. (2011). Pengaruh Partisipasi Masyarakat, Transparansi Kebijakan Publik, Akuntabilitas Publik Dan Pengetahuan Dewan Tentang Anggaran Terhadap Penyusunan APBD (Studi Empiris Pada DPRD Kota Surakarta Jawa Tengah). Tesis. Surakarta : Universitas Muhamadiyah Surakarta

Lestari, S.N.D. (2014). Analisis Faktor-Faktor yang Mempengaruhi Kinerja Pengelolaan Keuangan Perguruan Tinggi Negeri. Tesis. Yogyakarta: Universitas Gadjah Mada. 
Listya, H. K. (2011). Pengaruh Partisipasi Masyarakat Terhadap Tingkat Keberhasilan Proyek Pemberdayaan Masyarakat Di Kabupaten Banyuwangi, Tesis Surabaya: ITS Surabaya.

Murray, D. (1990). The Performance Effects of Participative Budgeting: An Integration of Interventing and Moderating Variables. Behavior Research In Accounting, 2, 104-121.

Mulgan, R. 2000. Accountability: An Ever-Expanding Concept? Journal Public Administration, 78 (3), $555-576$.

Myers. D.G. (2002). Social Psychology. 7th Edition. North America: McGrow-Hill.Inc

Nurjaman, R. 2015. Dinamika dan Problematika Implementasi UU Desa: Pembelajaran dari 3 Daerah di Jawa Barat. Jurnal Desentralisasi, 13(1).

Patton, J.M. (1992). Accountability and Governmental Financial Reporting, Journal of Financial Accountability and Management Autumn, 150-165.

Peraturan Pemerintah Republik Indonesia Nomor 60 Tahun 2014, tentang Dana Desa Yang Bersumber Dari Anggaran Pendapatan dan Belanja Negara.

Peraturan Bupati Karangasem Nomor 23 Tahun 2015 tentang Tata Cara Pembagian dan Penetapan Rencana Dana Desa setiap Desa di Kabupaten Karangasem Tahun Anggaran 2015.

Putra, IGM. (2000). THK dalam Arsitektur Bali, dalam Kumpulan Makalah Konsep dan Implementasi THK dalam Pembangunan Bali Menyongsong Pelaksanaan Otonomi Daerah, Pusat Kajian Bali

Raharja, G. P., Herawati, N. T., Purnamawati I G. A. (2015). Pengaruh Akuntabilitas, Partisipasi Masyarakat dan Pengawasan Internal Terhadap Kinerja Organisasi (Pada Dinas Pekerjaan Umum Kabupaten Buleleng). Jurnal Akuntansi Universitas Pendididkan Ganesha, 3(1).

Randa, F. (2013). Memahami Dimensi Akuntabilitas pada Organisasi Pemerintah Daerah (Studi etnografi pada pemerintah Kabupaten Tana Toraja). Proceeding Simposium Nasional Akuntansi.

Randa, F., \& Daromes, F.E. (2014). Transformasi Nilai Budaya Lokal dalam Membangun Akuntabilitas Organisasi Sektor Publik. Jurnal Akuntansi Multiparadigma, 5(3), 477-484.
Raharjo, T. Sjamsuddin, S. Hardjanto, I. (2013). Implementasi Kebijakan Alokasi Dana Desa (ADD) Tahun 2011 Di Desa Jembul dan Desa Sumengko Kecamatan Jatirejo Kabupaten Mojokerto. Jurnal Administrasi Publik, 16(1).

Retnaningtyas, T. W. (2016). Analisis Akuntabilitas Kinerja Keuangan Satuan Kerja Perangkat Daerah Kota Surakarta. Naskah publikasi. Surakarta, Universitas Muhammadiyah Surakarta.

Rosalinda, O. (2014). Pengelolaan Alokasi Dan Desa Dalam Menunjang Pembangunan Desa Jurnal lmiah: Malang, Universitas Brawijaya. Robbins, S., Judge P, Timothy A. (2009). Organizational Behaviour, Diana Angelica, Ria Cahyani, dan Abdul Rosyid (penerjemah). Perilaku Organisasi. Edisi 12. Jakarta, Salemba Empat.

Rofika \& Ardianto. (2014). Pengaruh Penerapan Akuntabilitas Keuangan, Pemanfaatan Teknologi Informasi, Kompetensi Aparatur Pemerintah Daerah dan Ketaatan Terhadap Peraturan Perundagan Terhadap Akuntabilitas Kinerja Instansi Pemerintah. Jurnal Akuntansi, 2(2), 197-209.

Sande, P. (2013). Pengaruh Penyajian Laporan Keuangan dan Aksesibilitas Laporan Keuangan terhadap Akuntabilitas Pengelolaan Keuangan Daerah (Studi Empiris pada Pemerintah Provinsi Sumatera Barat). Tesis. Padang: Universitas Negeri Padang.

Santoso, E. B. (2016). Pengaruh Sistem Pengendalian Intern Pemerintah, Pemanfaatan Teknologi Informasi Dan Kompetensi Sumber Daya Manusia Terhadap Akuntabilitas Keuangan Daerah (Studi Empiris pada Pemerintah Kabupaten Lampung Timur). Tesis. Bandar Lampung: Universitas Lampung.

Sapta, S. I. K., (2017). Peran Komitmen Organisasional Memediasi Hubungan Nilai Kepemimpinan dan Budaya Tri Hita Karana dengan Kinerja Subak di Bali. Disertasi. Denpasar: Universitas Udayana.

Sarwono, S. W. (2002). Psikologi Sosial, Individu dan Teori-Teori Psikologi Sosial. Jakarta: Balai Pustaka.

Scott, C. (2000). Accountability in The Regulatory State. Journal of Law and Society, 27(1), 3860.

Sears, D. O., Fredman, J.L., \& Peplau, L. A. (1991). Psikologi Sosial. Jilid 2 (Michael Adryanto). Jakarta, Erlangga 
Soetomo. (2006). Strategi-Strategi Pembangunan Masyarakat. Yogyakarta, Pustaka Pelajar.

Solimun. (2010). Pemodelan Persamaan Struktural Pendekatan PLS, Fakultas MIPA Universitas Brawijaya, Malang.

Sopanah. (2003). Pengaruh Partisipasi Masyarakat dan transparansi kebijakan publik terhadap hubungan antara pengetahuan dewan tentang anggaran dengan pengawasan keuangan daerah. Tesis.Yogyakarta:Universitas Gajah Mada.

Suarmanayasa, I. N. (2017). Pengaruh Modal Sosial, Partisipasi Masyarakat dan Kinerja Lembaga Perkreditan Desa terhadap Keberhasilan Pembangunan Perdesaan di Provinsi Bali Disertasi. Denpasar: Universitas Udayana.

Subroto, A. (2009). Akuntabilitas Pengelolaan Dana

Desa (Studi Kasus Pengelolaan Alokasi Dana Desa) Di Desa-Desa Dalam Wilayah Kecamatan Tlogomulyo Kabupaten Temanggung Tahun 2008. Tesis. Semarang: Universitas Diponegoro.

Sudiarianti, N. M. (2013). Pengaruh Kompetensi Sumber Daya Manusia pada Penerapan Sistem Pengendalian Intern Pemerintah dan Standar Akuntansi Pemerintah serta Implikasinya pada Kualitas Laporan Keuangan Pemerintah Daerah, Tesis. Denpasar: Universitas Udayana.

Sujana, K., Dwirandra, A. A. NB., Putri I G. A. M., Asri D., \& Suardika, S. (2015). Akuntabilitas dalam Perspektif Budaya Lokal pada Lembaga Perkreditan Desa (LPD). Laporan penelitian. Denpasar: Universitas Udayana.

Supartha, W. G. (2006). Pengaruh Kebijakan Pemerintah Kabupaten/Kota dan Kepemimpinan terhadap Budaya Organisasi dan Disiplin Pegawai serta Kinerja Puskesmas di Provinsi Bali, Disertasi. Surabaya: Universitas Airlangga. Suriana, (2009). Analisis Keberlanjutan Pengelolaan Sumber Daya Laut Gugus Pulau Keledupa Berbasis Partisipasi Masyarakat, Tesis. Bogor: Institut Pertanian Bogor.

Surya, I. B. K., Thoyib, A.,Fatchan,A., \& Rahayu, M. (2014). Tri Hita Karana Culture Effect on Company Performance, Leadership and Organizational Commitment (Studies an Regional Water Company in Bali Province). International Journal of Business and Management Invention, 3, 13-22.

Surpha, I. W. (2004). Eksistensi Desa Adat dan Desa Dinas di Bali. Denpasar: Pustaka Bali Post.
Sukijan. (2012). Pengaruh Kepemimpinan Kepala Desa Terhadap Partisipasi Masyarakat dalam Pembangunan di Desa Studi Kasus di Desa Bukit Pamewa Kecamatan Sipora Utara Kabupaten Kepulauan Mentawai Tahun 2011. Tesis. Yogyakarta: Universitas Gajah Mada.

Thomas. 2013. Pengelolaan Alokasi Dana Desa Dalam Upaya Meningkatkan Pembangunan Di Desa Sebawang Kecamatan Sesayap Kabupaten Tana Tuding. Journal Pemerintahan Integratif, 1(1), 51-64.

Tuan, B. H. (2009). Partisipasi Masyarakat dalam Pemanfaatan Alokasi Dana Desa melalui Penguatan Kelembagaan di Kabupaten Mappi. Tesis. Yogyakarta: Universitas Gajah Mada.

Tyler. Tom R. (1990). Why People Obey the Law. Yale University Press.

Triyuwono, I. (2002). Kearifan Lokal: Internalisasi "Sang lain" Dalam Dekonstruksi Pengukuran Kinerja Manajemen. Paper presented at the Seminar Regional Sehari "Emansipasi Kearifan Lokal Untuk Rekonstruksi Sistem Ekonomi dan Bisnis, Fakultas Ekonomi: Universitas Brawijaya.

Umboh, F. A. (2004). Peningkatan Partisipasi Masyarakat dalam Pembangunan Desa di Desa Pinili Kecamatan Dimembe Kabupaten Minahasa. Tesis. Bogor: Institut Pertanian Bogor. Undang- Undang Nomor 3 Tahun 2015 tentang

Perubahan Atas Undang-Undang Nomor 27

Tahun 2014 Tentang Anggaran Pendapatan dan

Belanja Negara Tahun Anggaran 2015.

Undang-Undang Nomor 6 Tahun 2014 tentang Desa. Wiana, I. K. (2007). Tri Hita Karana Menurut Konsep Hindu: Penerbit Paramita Surabaya. Widyarini, N. (2005). Prosocial behavior: Mengapa Orang Mau Menolong Orang Lain?

Wirajaya, G. A. (2014). Studi Etnografi tentang Akuntabilitas Organisasi Desa Adat Kuta Bali Disertasi. Malang: Universitas Brawijaya

Werimon, S. (2005). Pengaruh Partisipasi Masyarakat dan Transparansi Kebijakan Publik terhadap Hubungan Antara Pengetahuan Dewan tentang Anggaran dengan Pengawasan Keuangan Daerah (APBD). Tesis. Semarang: Universitas Diponegoro

Wulandari, P. R. (2013). Analisis Partisipasi Masyarakat dan kepemimpinan terhadap tingkat keberhasilan Proyek Program Nasional Pemberdayaan Masyarakat (PNPM) Mandiri 
Perdesaan di Kecamatan Gerokgak, Buleleng Tesis. Denpasar: Universitas Udayana.

Zirman. (2010). Pengaruh Kompetensi Aparatur Pemerintah Daerah, Penerapan Akuntabilitas
Keuangan, Motivasi Kerja, dan Ketaatan pada Peraturan Perundangan terhadap Akuntabilitas Kinerja Instansi Pemerintah. Jurnal Ekonomi, $18,1-10$. 